\title{
Myosittspesifikke autoantistoffer
}

\author{
Sammendrag \\ Bakgrunn. Med myosittspesifikke anti- \\ stoffer (MSA) menes autoantistoffer \\ som nesten utelukkende påvises ved \\ idiopatiske inflammatoriske myopatier \\ (IIM). Artikkelen gir en oversikt over \\ disse autoantistoffene og hvordan \\ de kan brukes klinisk til å identifisere \\ undergrupper av idiopatiske inflamma- \\ toriske myopatier.
}

\begin{abstract}
Materiale og metode. Artikkelen er basert på ikke-systematiske litteratursøk og egne erfaringer.
\end{abstract}

Resultater. Hos opp mot $50 \%$ av pasienter med idiopatiske inflammatoriske myopatier kan det påvises myosittspesifikke antistoffer. De hyppigst forekommende av disse er antisyntetaseantistoffer som kan påvises hos pasienter med antisyntetasesyndrom. Hos slike pasienter dominerer interstitiell lungesykdom det kliniske bildet. Et annet myosittspesifikt autoantistoff er anti-Mi-2-antistoff, som påvises hos de fleste pasienter med dermatomyositt. Pasienter med anti-SRP-autoantistoff kjennetegnes av alvorlig myopati, dårlig respons på behandling med kortikosteroider og få inflammatoriske infiltrater ved muskelbiopsi. AntiCADM-140-antistoff ses særlig hos pasienter med amyopatisk eller hypomyopatisk dermatomyositt som tidligere ble betegnet som dermatomyositis sine myositis. Anti-p55-antistoff er i foreløpige rapporter særlig funnet hos pasienter med samtidig kreftsykdom.

Fortolkning. Myosittspesifikke antistoffer kan være et egnet verktøy til å identifisere kliniske undergrupper av idiopatiske inflammatoriske myopatier og dermed påvirke valg av medikamentell behandling.
Jan Tore Gran

jan.tore.gran@rikshospitalet.no

Øyvind Molberg

Gerd Cecilie Dobloug

Helena Andersson

Revmatologisk avdeling

Eli Taraldsrud

Immunologisk institutt

David Scheie

Avdeling for patologi

Oslo universitetssykehus, Rikshospitalet 0027 Oslo

Idiopatiske inflammatoriske myopatier omfatter en gruppe sykdommer som kjennetegnes ved en kronisk, destruktiv inflammasjon i tverrstripet muskulatur. Tradisjonelt er sykdommene blitt delt inn i tre undergrupper: polymyositt, dermatomyositt og inklusjonslegememyositt (1). Klinisk karakteriseres polymyositt og dermatomyositt av symmetrisk kraftreduksjon i proksimal muskulatur. Begge sykdommer ledsages ikke sjelden av interstitiell lungesykdom. Ved dermatomyositt opptrer det i tillegg ulike hudmanifestasjoner, og hos voksne diagnostiseres samtidig kreftsykdom hos 26-47\% av pasientene $(2,3)$. Det er usikkert om inklusjonslegememyositt er en immunmediert sykdom, og tilstanden omtales derfor ikke videre i denne artikkelen.

Diagnostikken av inflammatorisk muskelsykdom baseres på det kliniske bildet, funn av myopatiske forandringer ved elektromyografi (EMG), forhøyde verdier av muskelenzymer i serum (kreatinkinase) og karakteristiske histologiske forandringer ved muskelbiopsi (1). Det histologiske bildet ved polymyositt varierer, men typisk finner man celleinfiltrasjon i musklenes endomysium. Disse celleinfiltratene består i all hovedsak av CD8-positive T-celler (cytotoksiske T-lymfocytter), hvor noen av cellene lokaliseres inne i ikke-nekrotiske muskelfibre (4). Man finner en generell oppregulering av MHC1 på samtlige muskelfibres cellemembran. Ved dermatomyositt er det typiske histologiske bildet annerledes med perifascikulære celleinfiltrater bestående av B-lymfocytter og CD4-positive celler (Thjelpelymfocytter, eller plasmacytoide dendrittiske celler) (4). Vanligvis påvises perifascikulær oppregulering av MHC1 og ofte, særlig hos barn, perifascikulær atrofi av muskelfibrene. At betennelsesprosessen ved dermatomyositt hovedsakelig sentraliseres rundt perifascikulære blodkar, kan tolkes dithen at dermatomyositt i større grad er en karsykdom, eventuelt endotelsykdom, enn en primær muskelsykdom.

Den tradisjonelle og enkle inndelingen av de inflammatoriske myopatier forklarer ikke den store variasjonen i klinisk bilde og sykdomsforløp mellom pasienter. Inndelingen inkluderer heller ikke pasienter som har klassisk hudutslett, men lite eller ingen muskelaffeksjon (hypomyopatisk og amyopatisk dermatomyositt). Andre undergrupper inflammatoriske myopatier som ikke omfattes av denne inndelingen, er myositt assosiert med kreftsykdom og alvorlig kortikosteroidresistent myositt.

Det kanskje viktigste ankepunktet mot den gjeldende inndelingen er at den ikke tar hensyn til at en betydelig andel av pasientene med klinisk poly- eller dermatomyositt har distinkte og sykdomsspesifikke serumautoantistoffer. Hensikten med denne artikkelen er å gi en oppdatert oversikt over disse autoantistoffene og vise hvordan de kan benyttes til å identifisere kliniske undergrupper av inflammatorisk myopati, og på den måten være rettledende for valg av medikamentell behandling og forutsigelse av sykdomsutfall.

\section{Materiale og metode}

Artikkelen er basert på ikke-systematiske litteratursøk og klinisk erfaring i bruk av myosittspesifikke antistoffer.

\section{Myosittspesifikke autoantistoffer}

Ved de idiopatiske inflammatoriske myopatier kan det hos opp mot halvparten av pasientene påvises myosittspesifikke autoantistoffer (5-8). Med myosittspesifikke autoantistoffer menes autoantistoffer som nesten utelukkende påvises ved idiopatiske inflammatoriske myopatier (9). Disse må skilles fra de myosittassosierte autoantistoffer, som er antistoffer som finnes ved systemiske bindevevssykdommer hvor myositt opptrer som

\section{Hovedbudskap}

- Bestemmelse av myosittspesifikke autoantistoffer kan være til hjelp ved klassifikasjon av inflammatorisk myopati og valg av behandling

- Analysene bør kun utføres hos pasienter hvor diagnosen inflammatorisk myopati er sikker 


\section{Antisyntetaseantistoffer}

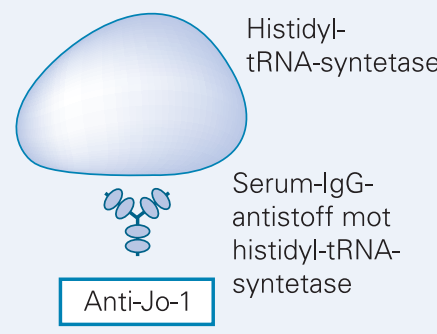

Aminoacyl-tRNA-syntetase
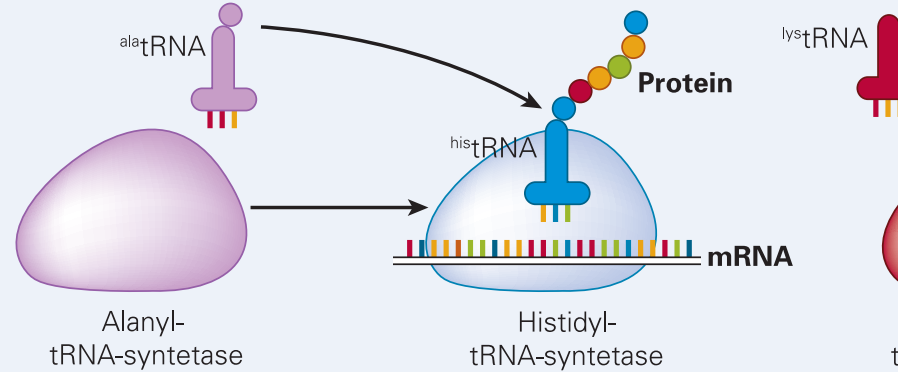

Figur 1 Funksjon av aminoacyl-transfer-RNA-syntetaseproteiner. Hvert enkelt amino-acyltransfer-RNA-syntetase katalyserer overføringen av en enkelt aminosyre fra transfer-RNA til polypeptidkjeden under proteinsyntesen

en av flere manifestasjoner (10). Disse omtales ikke videre her.

Felles for de myosittspesifikke autoantistoffene er at de er spesifikke for kroppsegne, men evolusjonært konserverte, proteiner som har kritisk viktige funksjoner i alle celler. Det er svært sjelden at det hos en pasient dannes mer enn et enkelt myosittspesifikt autoantistoff (11). Autoantistoffenes rolle i patogenesen av inflammatorisk myopati, og i hvilken grad deres nivå påvirkes av sykdomsaktivitet og behandling er ufullstendig klarlagt. I dag ser man konturene av fem ulike kliniske undergrupper som hver er forbundet med tilhørende myosittspesifikke autoantistoffer. I denne artikkelen omtales antisyntetaseantistoffer, anti-Signal Recognition Particle-antistoff (anti-SRP-antistoff), anti-Mi-2-antistoff, anti-CADM-140antistoff og anti-p155-antistoff (tab 1).

\section{Antisyntetase autoantistoffer}

Antisyntetaseantistoffer omfatter flere ulike antistoffer rettet mot distinkte aminoacyltransfer-RNA-syntetaseproteiner. Hver enkelt aminoacyl-transfer-RNA-syntetase katalyserer overføringen av en enkelt distinkt aminosyre fra transfer-RNA til polypeptidkjeden

Tabell 1 Myosittspesifikke autoantistoffer

\begin{tabular}{lll} 
Myosittspesifikt autoantistoff & Antigen & Klinisk tilstand \\
\hline Antisyntetaseantistoffer & & \\
\hline Anti-Jo-1 & Histidyl-tRNA-syntetase & Antisyntetasesyndrom \\
Anti-PL-7 & Treonin-tRNA-syntetase & Antisyntetasesyndrom \\
Anti-PL-12 & Alanin-tRNA-syntetase & Antisyntetasesyndrom \\
Anti-OJ & Isoleucyl-tRNA-syntetase & Antisyntetasesyndrom \\
Anti-EJ & Glycyl-tRNA-syntetase & Antisyntetasesyndrom \\
Anti-Zo & Fenylalanin-tRNA-syntetase & Antisyntetasesyndrom \\
\hline Anti-YRS & Tyrosyl-tRNA-syntetase & Antisyntetasesyndrom \\
Anti KS & Asparaginyl-tRNA-syntetase & Antisyntetasesyndrom \\
Anti-Mi-2-antistoff & & Dermatomyositt \\
Anti Signal Recognition & & Alvorlig steroidresistent \\
Particle-antistoff (SRP) & & myositt \\
\hline Anti-CADM-140 & & Amyopatisk og hypomyopa- \\
& & tisk dermatomyositt \\
Anti-p155 & & Cancerassosiert myositt
\end{tabular}

under proteinsyntesen (fig 1). Disse antistoffene kan påvises hos opp mot $30 \%$ av pasienter med idiopatiske inflammatoriske myopatier (12). De ulike antisyntetaseantistoffene som hittil er identifisert, er vist i tabell 1. Det hyppigst forekommende antisyntetaseantistoffet er rettet mot histidyl-transfer- RNAsyntetase (anti-Jo-1-antistoff) $(13,14)$.

Pasienter med antisyntetaseantistoffer kjennetegnes klinisk ved det såkalte antisyntetasesyndromet (15). Den viktigste kliniske manifestasjonen ved dette syndromet er interstitiell lungesykdom som utvikles hos nærmere $95 \%$ av pasientene, og kan tidlig i sykdomsforløpet være eneste sykdomsmanifestasjon $(15,16)$.

Det ses tre ulike forløpsformer av interstitiell lungesykdom ved antisyntetasesyndrom (ramme 1). Disse forløpsformene har svært ulik prognose og således behov for differensierte behandlingsopplegg. Ved type 1, interstitiell lungesykdom, (ramme 1) er dødeligheten høy (17), og behandling skal igangsettes umiddelbart. Her har man vist at en kombinasjonsbehandling av immunsuppressiver fra starten av gir bedre overlevelse enn ved såkalt eskalerende behandling hvor slike medikamenter legges fortløpende til avhengig av sykdomsutviklingen $(18,19)$. Ved vår avdeling benyttes i dag en kombinasjon av kortikosteroider, cyklofosfamid og monoklonalt anti-CD20-antistoff (rituximab). Andre behandlingsalternativer er ciklosporin $(20,21)$ og tacrolimus $(22)$. Ved type 2 , interstitiell lungesykdom, benyttes cyklofosfamid og kortikosteroider. Muskelsykdommen ved antisyntetasesyndrom kan være lite eller moderat uttalt og sjelden avgjørende for sykdomsforløp og utfall (15). Histologisk finner man som regel et dermatomyosittliknende bilde med perifascikulær atrofi og perimyseal inflammasjon (12). Foruten muskelsvakhet og muskelstivhet kan antisyntetasesyndrom klinisk ytre seg ved «mekaniker»-hender, Gottrons papler og tegn, Raynauds fenomener, artritt og siccasymptomer (15). Tidligere mente man at den økte risikoen for kreftsykdom ved dermatomyositt ikke omfattet pasienter med anti-Jo-1-antistoff $(23,24)$. Kasuistiske meddelelser om samtidig opptreden av kreftsykdom hos slike pasienter viser at besittelse av dette autoantistoffet ikke gir noen absolutt beskyttelse mot koeksisterende kreftsykdom (25). Blant de 45 pasientene med antisyntetasesyndrom vi har behandlet de siste fem år, har tre pasienter hatt samtidig malign lidelse.

\section{Anti-SRP-autoantistoffer}

Signal Recognition Particle er et protein som inngår $i$ et større RNA-proteinkompleks. Funksjonen til dette komplekset er å transportere nysyntetiserte, sekretoriske proteiner fra ribosomene til endoplasmatisk retikulum (9). Ved idiopatisk inflammatorisk myopati kan man hos 5-10\% påvise et antistoff rettet mot dette komplekset. 
Pasienter med anti-SRP-antistoff kjennetegnes av relativt akutt innsettende og alvorlig myosittsykdom, ofte ledsaget av Raynauds fenomener og dysfagi $(26,27)$. Interstitiell lungesykdom ses hos omkring en femdel (27). Ved muskelbiopsi finner man hos de fleste av pasientene med anti-SRPantistoff et uvanlig histologisk bilde med uttalt nekrose av muskelfibre uten ledsagende infiltrater av betennelsesceller $(9,26$, 27). Et slikt histologisk bilde ses også ved kreftassosiert nekrotiserende myopati (1). Anti-SRP-positiv myopati synes å svare dårlig på tradisjonell behandling med kortikosteroider, mens derimot behandling med rituximab kan være effektivt $(9,27)$.

\section{Anti-Mi-2-autoantistoffer}

Anti-Mi-2-antistoff gjenkjenner et $240 \mathrm{kDa}$ stort protein kalt Mi-2a. Dette proteinet, som funksjonelt er en DNA-helikase, inngår i NURD-komplekset, et kritisk viktig DNAbindende multiproteinkompleks (9). AntiMi-2-antistoffer kan påvises med ulike metoder, men dessverre varierer de mye med hensyn til spesifisitet og sensitivitet. Ved bruk av tester basert på immundiffusjon eller immunpresipitering av Mi-2 vil nesten alle med positiv test ha dermatomyositt (12). Dersom ELISA-teknikk anvendes, vil kanskje ikke flere enn $20-50 \%$ av pasienter med anti-Mi2-antistoff ha dermatomyositt $(4,12,28)$. Med en slik påvisningsmetode vil anti-Mi-2antistoff også kunne påvises hos pasienter med polymyositt, inklusjonslegememyositt og uklassifiserbar myosittsykdom $(4,12$, 28). Det er foreløpig uklart om det er vesentlige kliniske forskjeller mellom dermatomyositt med og uten anti-Mi-2-antistoff.

\section{Anti-CADM-140-autoantistoff}

Serum-IgG-antistoffer mot et protein kalt CADM 140 (clinically amyopathic dermatomyositis, $140 \mathrm{kDa}$ protein) ser ut til å kunne identifisere en undergruppe av pasienter som har klassiske hudforandringer forenlig med dermatomyositt, men lite eller ingen muskelaffeksjon (dermatomyositis sine myositis) (29-31). Et slikt sykdomsbilde omtales i dag som enten amyopatisk dermatomyositt eller hypomyopatisk dermatomyositt. Pasienter med amyopatisk dermatomyositt har verken kliniske symptomer på muskelsykdom, eller laboratoriefunn tydende på en slik sykdom (32). Ved hypomyopatisk dermatomyositt mangler også kliniske symptomer på muskelsykdom, men man har her minst ett laboratoriefunn (histologiske forandringer, forhøyde verdier av muskelenzymer, eller elektromyografiske forandringer) tydende på inflammatorisk myopati (32). Anti-CADM140-antistoffer er foreløpig bare beskrevet i studier fra Japan (33). Identiteten til det 140 $\mathrm{kDa}$ store proteinet som gjenkjennes av antiCADM-140- antistoffene, er foreløpig ikke kjent (9). De foreliggende resultatene tyder på at omkring $50 \%$ av pasienter med amyopatisk dermatomyositt har dette autoantistof- fet (9), og forekomsten synes særlig høy hos de pasienter som vil utvikle interstitiell lungesykdom $(33,34)$. Da mange av disse pasientene vil utvikle alvorlig progredierende lungesykdom tidlig i sykdomsforløpet, kan bestemmelse av anti-CADM-140 muligens bidra til å identifisere en undergruppe som har behov for tidlig immunsuppressiv behandling $(35,36)$.

\section{Anti-p155-antistoff}

Serum-antistoffer mot et $155 \mathrm{kDa}$ humant protein hos pasienter med inflammatorisk myopati ble først beskrevet i 2006, og senere studier har vist at anti-p55-antistoffer kan bli et nyttig diagnostisk og prognostisk hjelpemiddel hos både voksne og barn med inflammatorisk myopati (38). Den første studien av anti-p155 viste at antistoffene forekom hos om lag en femdel av pasientene med barneformen av dermatomyositt. Selv om spesifisiteten til anti-p55-antistoffene ikke er endelig klarlagt, tyder tilgjengelige data på at de er rettet mot det DNA-bindende proteinet transkripsjonell intermediær faktor 1 gamma (TIF1 $\gamma$ ) (38). Det finnes per i dag ingen kommersiell test som påviser antistoff mot $155 \mathrm{kDa}$-proteinet.

I den første anti-p155-rapporten ble det også beskrevet en økt forekomst av antistoffet hos pasienter med kreftassosiert myopati (37). Dette funnet er bekreftet i studier både fra Japan og fra Storbritannia. Samlet sett peker disse studiene i retning av at anti-p155 kan være til stede hos ca. halvparten av pasientene med inflammatorisk myopati og samtidig malign sykdom. Anti-p155 kan således $\mathrm{i}$ fremtiden muligens benyttes som en biomarkør for ledsagende kreftsykdom hos voksne pasienter med inflammatorisk myopati. Det er ikke funnet noen tilfeller av malign sykdom hos de anti-p155-antistoffpositive barna med inflammatorisk muskelsykdom.

\section{Når rekvirere myosittspesifikke autoantistoffer?}

Bestemmelse av myosittspesifikke autoantistoffer utover påvisning av anti-Jo-1, antiPL-7, anti-PL-12 og Mi-2-antistoffer er foreløpig ikke tilgjengelig ved norske laboratorier. Analyse av de øvrige antisyntetaseantistoffene og anti-SRP-antistoff gjøres imidlertid ved flere utenlandske laboratorier. Immunologisk institutt ved Rikshospitalet har også introdusert disse analysene, men foreløpig bare som ledd i et forskningsprosjekt. Felles for alle de kommersielle MSAanalysene er at de foreløpig kun er prøvd ut $i$ små pasientmaterialer. Tolkingen av resultatene krever derfor betydelig klinisk erfaring med denne pasientgruppen.

Idiopatiske inflammatoriske myopatier er sjeldne sykdommer, mens derimot utredning av pasienter med muskelsymptomer utgjør en tallmessig stor utfordring i mange kliniske sammenhenger. Bestemmelse av myosittspesifikke autoantistoffer skal ikke utføres rutinemessig i denne utredningen. Slik vi

\section{Ramme 1}

\section{Klinisk klassifikasjon av interstitiell lungesykdom ved idiopatisk inflammatorisk myopati}

Type 1: Alvorlig lungesykdom med utvikling av hypoksi innen fire uker

Type 2: Gradvis progredierende interstitiell lungesykdom

Type 3: Asymptomatisk interstitiell lungesykdom påvist radiologisk

ser det, bør dette bare utføres hos pasienter hvor man med sikkerhet vet at det foreligger en idiopatisk inflammatorisk myopati. Forhøyede verdier av muskelenzymer i serum (kreatinkinase), kraftsvikt i proksimal muskulatur, myopatiske forandringer ved EMG og inflammatorisk myopati påvist ved muskelbiopsi bør ligge til grunn for en sikker diagnose (1).

Ved opptreden av klassiske hudforandringer som Gottrons papler, og heliotropt utslett og eventuell perifascikulær inflammasjon ved muskelbiopsi foreligger det høyst sannsynlig dermatomyositt, og hos voksne pasienter bør man undersøke for samtidig kreftsykdom. Det er de kreftsykdommer man oftest finner i tilsvarende aldersgruppe som er overrepresentert ved dermatomyositt, bortsett fra hos asiater hvor nasofaryngeal kreftsykdom dominerer (39). Bestemmelse av anti-Mi-2-antistoff vil styrke diagnosen ytterligere, men har utover dette ingen annen verdi. Dersom det ved dermatomyositt i tillegg finnes interstitiell lungesykdom, bør bestemmelse av anti-Jo-1-antistoff rekvireres, da diagnosen antisyntetasesyndrom ofte innebærer valg av annen immunsuppressiv behandling. Ved vår avdeling vil vi hos pasienter med klinisk mistenkt antisyntetasesyndrom og negativ test for anti-Jo-1antistoff unders $ø$ ke for andre antisyntetaseantistoffer (tab 1). Hos pasienter under utredning for idiopatisk lungefibrose (fibroserende alveolitt) kan også bestemmelse av anti-Jo-1-antistoff være av nytte for å identifisere pasienter med begynnende antisyntetasesyndrom. Dette vil være aktuelt for pasienter med symptomgivende og progredierende lungesykdom (type 1 og 2).

Hos pasienter som ved muskelbiopsi får påvist muskelnekrose uten særlig inflammasjon, eller som ikke svarer adekvat på behandling med kortikosteroider, vil vi utføre bestemmelse av anti-SRP-antistoff. Hos pasienter med anti-SRP-positiv myopati vil tidlig behandling med immunsuppressiver være av betydning for sykdomsutfall. Pasienter med histologisk påvist muskelcellenekrose uten samtidig inflammasjon og uten påvisbare anti-SRP-antistoffer bør screenes for koeksisterende kreftsykdom.

Bestemmelse av anti-CADM-140 og anti- 
p55-antistoff er ikke kommersielt tilgjengelig, men vil sannsynligvis i fremtiden kunne benyttes til klassifikasjon av amyopatisk og hypomyopatisk dermatomyositt samt cancerassosiert myopati.

\section{Konklusjon}

Idiopatiske inflammatoriske myopatier er sjeldne sykdommer, men deres alvorlighetsgrad reiser imidlertid et behov for korrekt diagnostikk og klassifikasjon. De senere års funn av autoantistoffer som nesten utelukkende kan påvises ved idiopatisk inflammatorisk myopati, har i stor grad bidratt til å øke vår forståelse av sykdomsmekanismene og sykdomsforløpet ved disse sykdommene. I tiden fremover vil bestemmelse av slike autoantistoffer kunne bli et nyttig hjelpemiddel for å identifisere kliniske undergrupper og på den måten være rettledende for valg av medikamentell behandling og forutsigelse av sykdomsutfall.

Oppgitte interessekonflikter: Ingen

\section{Litteratur}

1. Bohan A, Peters JB. A computer-assisted analysis of 153 patients with polymyositis and dermatomyositis. Medicine 1977: 56: 255-86.

2. Duncan AG, Richardson JB, Klein JB et al. Clinical, serologic and immunogenetic studies in patients with dermatomyositis. Acta Derm Venereol 1990; 71: 312-6

3. Baron M, Small P. Polymyositis/dermatomyositis: clinical features and outcome in 22 patients. J Rheumatol 1985; 12: 283-6.

4. Hengstman GJD. Advances in the immunopathophysiology of the idiopathic inflammatory myopathies: not as simple as suspected. Curr Rheumatol Rep 2007; 9: 280-5.

5. Hirakata M. Autoantibodies and their clinical sig nificance in idiopathic inflammatory myopathies: polymyosits/dermatomyositis and related conditions. Nihon Rinsho Meneki Gakkai Kaishi 2007; 30: $444-54$

6. Hausmanova-Petrusewicz I, Kowalska-Oledzka E Miller FW et al. Clinical, serologic, and immunogenetic features in Polish patients with idiopathic inflammatory myopathies. Arthritis Rheum 1997; 40: 1257-66.

7. Hengstman GJD, Brenk L, Vree Egberts WTM et al. High specificity of myositis specific autoantibodies for myositis compared with other neuromuscular disorders. J Neurol 2005; 252: 534-7.

8. Brouwer R, Hengstman GJD, Egberts WV et al. Autoantibody profiles in the sera of European patients with myositis. Ann Rheum Dis 2001; 60: $116-23$
9. Mimori T, Imura Y Kakashima R et al. Autoantibodies in idiopathic inflammatory myopathy; an update on clinical and pathophysiological significance. Curr Opin Rheumatol 2007; 19: $523-9$.

10. Targoff IN. Update on myositis-specific and myositis-associated autoantibodies. Curr Rheum Rep 2000; 12: 475-81.

11. Gelpi C, Kanterewicz E, Gratacos J et al. Coexistence of two antisynthetases in a patient with the antisynthetase syndrome. Arthritis Rheum 1996: 39: $692-7$.

12. Targoff IN. Myositis specific autoantibodies. Curr Rheumatol Rep 2006; 8: 196-203

13. Hengstman GJD, van Engelen BGM, Vree Egberts WTM et al. Myositis-specific autoantibodies: overview and recent developments. Curr Opin Rheum 2001; 13: 476-82.

14. Selva-O'Callaghan A, Labrador-Horrillo M, SolansLaque $\mathrm{R}$ et al. Myositis-specific and myositis-associated antibodies in a series of eighty-eight Mediterranean patients with idiopathic inflammatory myopathy. Arthritis Rheum 2006; 55: 791-9.

15. Gran JT. Antisyntetasesyndrom. Tidsskr Nor Lægeforen 2002; 122: 2270-2.

16. Yoshifuji H, Fujii T, Kobayashi S. Anti-aminoacylRNA synthetase antibodies in clinical course prediction of interstitial lung disease complicated with inflammatory myopathies. Autoimmunity 2006; 39 ; $233-41$

17. Suda $T$, Fujisawa $T$, Enomoto $\mathrm{N}$ et al. Interstitial lung diseases associated with amyopathic dermatomyositis. Eur Respir J 2006; 28: 1005-12.

18. Kotani T, Makino S, Takeuchi T et al. Early intervention with corticosteroids and cyclosporin A and 2-hour postdose monitoring improves the progno sis of acute/subacute interstitial pneumonia in dermatomyositis. J Rheumatol 2008; 35: 254-9.

19. Takada K, Kishi J, Miyasaka N. Step-up versus primary intensive approach to the treatment of interstitial pneumonia associated with dermatomyositis/polymyositis: a retrospective study. Mod Rheumatol 2007: 17: 123-30.

20. Nawata Y, Kurasawa K, Takabayashi K et al. Corticosteroid resistant interstitial pneumonitis in dermatomyositis/polymyositis: prediction and treatment with cyclosporine. J Rheumatol 1999; 26: 1527-33.

21. Nagasaka K, Harigai M, Tateishi M et al. Efficacy of combination treatment with cyclosporine $A$ and corticosteroids for acute interstitial pneumonitis associated with dermatomyositis. Mod Rheumatol 2003: 13: $231-8$

22. Ochi S, Nanki T, Takada T et al. Favourable outcomes with tacrolimus in two patients with refractory interstitial lung disease associated with polymyositis/dermatomyositis. Clin Exp Rheumatol 2005; 23: 707-10.23.Christopher-Stine L, Plotz $\mathrm{PH}$. Myositis: an update on pathogenesis. Curr Opin Rheum 2004; 16: $700-6$.

24. Chinoy H. Fertig N, Oddis CV et al. The diagnostic utility of myositis autoantibody testing for predicting the risk of cancer-associated myositis. Ann Rheum Dis 2007; 66: 1345-9

25. Legault D, McDermott J, Crous-Tsanaclis AM et al. Cancer-associated myositis in the presence of anti-Jo1 autoantibodies and the antisynthetase syndrome. J Rheumatol 2008; 35: 169-71.
26. Miller T Al-Lozi MT Lopate $G$ et al. Myopathy with antibodies to the signal recognition particle: clinical and pathological features. J Neurol Neurosurg Psychiatry 2002; 73: 420-8.

27. Kao AH, Lacomis D, Lucas M et al. Anti-signal recognition particle autoantibody in patients with and patients without idiopathic inflammatory myopathy. Arthritis Rheum 2004; 50: 209-15.

28. Hengstman GI, Brouwer R, Egberts WT. Clinical and serological characteristics of 125 Dutch myositis patients. Myositis specific autoantibodies aid in the differential diagnosis of the idiopathic inflammatory myopathies. J Neurol 2002; 249: $69-75$.

29. el-Azhary RA, Pakzad SY. Amyopathic dermatomyositis: retrospective review of 37 cases. J Am Acad Dermatol 2002; 46: 560-5.

30. Klein RQ, Teal V. Taylor $L$ et al. Number, characteristics, and classification of patients with dermatomyositis seen by dermatology and rheumatology departments at a large tertiary medical center. J Am Acad Dermatol 2007; 57: 937-43.

31. Zhang ZL, Lai AY, Xu D et al. Clinical analysis of 29 patients with clinically amyopathic dermatomyositis. Zhonghua Yi Xue Za Zhi 2007; 87: 1345-7.

32. Sontheimer RD. Would a new name hasten the acceptance of amyopathic dermatomyositis (dermatomyositis sine myositis) as a distinct subset within the idiopathic inflammatory dermatomyo pathies spectrum of clinical illness? J Am Acad Dermatol 2002; 46: 626-36.

33. Sato S, Hirakata M, Kuwana M. Autoantibodies to a 140-kd polypeptide, CADM-140, in Japanese patients with clinically amyopathic dermatomyositis. Arthritis Rheum 2005; 52: 1571 -6.

34. Hengstman GJD. Advances in the immunopathophysiology of the idiopathic inflammatory myopathies: Not as simple as suspected. Curr Rheumatol Rep 2007; 9: 280-5.

35. Toyoshima M, Sato A, Chida K et al. Clinicopathological features of interstitial pneumonia associated with amyopathic dermatomyositis. Nihon Kyobu Shikkan Gakkai Zasshi 1997; 35: $281-7$

36. Miyazaki E, Ando M, Muramatsu T et al. Early assessment of rapidly progressing interstitial pneumonia associated with amyopathic dermatomyositis. Clin Rheumatol 2007: 26: 436-9.

37. Targoff IN, Mamyrova G. Trieu EP. A novel antibody to a $155-\mathrm{kd}$ protein is associated with dermatomyositis. Arthritis Rheum 2006; 54: 3682-9.

38. Targoff IN, Trieu EP, Levy-Neto M. Autoantibodies to transcriptional intermediary factor- 1 gamma in dermatomyositis. Abstrakt. Arthritis Rheum 2006; 54 (suppl): 518

39. Peng JC, Sheen TS, Hsu MM. Nasopharyngeal carcinoma with dermatomyositis. Arch Otolaryngol Head Neck Surg 1995; 121: 1298-1301.

Manuskriptet ble mottatt 27.5. 2008 og godkjent 22.1. 2009. Medisinsk redaktør Trine B. Haugen. 